\title{
Chelating abilities, chemical, spectroscopic, and biological characterization of humic acids derived from solid olive cake compost
}

\author{
Badr, M. $\mathrm{H}^{* 1}$ and Safwat, N.A. ${ }^{2}$ \\ ${ }^{1}$ Chemistry Department, Faculty of Science, Al-Azhar University (Girls) \\ ${ }^{2}$ Regional Center for Mycology and Biotechnology, AL-Azhar University, Cairo, Egypt
}

Received: 24 May 2015 / Accepted: 30 June 2015

*Corresponding author: drbadrmh@yahoo.com

\begin{abstract}
Composting of the solid waste generated in large amount in a short time interval from olive industry environmentally very attractive due to increasing its value. On the other hand various authors showed that the characteristics of humic acids depend on the parent material they are extracted of, in addition to many other factors including composting conditions and geographical region. In the present work four samples of pure solid olive mill waste (olive cake) was naturally composted under four different atmospheric conditions without addition of any plant residues or any nutrients, for more than one year. Humic acids (HAs) were extracted from the composts and they were characterized by elemental analysis, FTIR, UV-visible spectroscopy and titration for reactive groups. The results show that the compost prepared as a compact small sphere of diameter $20 \mathrm{~cm}$ and kept in door at room temperature for more than one year gives a reduced form of humic acids of high maturity, high aromatic content, high carboxylic and phenolic contents and highest chelating ability for $\mathrm{Cu}^{+2}$ ions when compared with the results of five literature concerning commercial humic acids, The results of biological activity tests indicate in vitro, good antioxidant and anti bacterial activity, also exhibited mild antitumer but weak antiviral activity.
\end{abstract}

Keywords: $\mathrm{Cu}^{+2}$ ions removal / humic acids / solid olive mill waste / composting / elemental analysis / spectroscopic characterization

\section{Introduction}

Humic substances (HS) or humus represent mixture of relatively small organic components, which form supramolecular structures held together by dispersive forces such as $\pi-\pi$ and van der Waals interactions De Pasquale et al. (2008). Assessment of the best analytical method for complete HS characterization is still being discussed, Naděžda and Lubica (2010). They are often, classified into three major groups (fractions) according to their solubility; humic acids (HA) insoluble below $\mathrm{pH} 2$, fulvic acids (FA) soluble at any $\mathrm{pH}$ and humins insoluble at any $\mathrm{pH}$. The HA fraction consist aliphatic and aromatic structures with linked peptides, amino 
compounds, and fatty acids Schnitzer and Khan (1978).

Humic acids contain large number of functional groups. The commonly encountered ionizable functional groups include carboxylic phenolic, alcoholic groups, ammonium ions, and thiols. To a lesser extent, sulfonic and "active methylene Gyula (2012). Due to poly functionality, humic acids are one of the most powerful chelating agents among natural organic substances. They are ideal as sorption medium for a number of water impurities and especially for heavy metals Chatterjee et al. (2013).

Heavy metals penetrate the soil from various sources and modify the soil properties. Heavy metals are a serious problem for the whole ecosystem particular. They are taken up by plants and then passed on to subsequent links in the food chain. While $\mathrm{Cu}$ is an essential micronutrient, exposure to excess $\mathrm{Cu}$ has detrimental effects. It has toxic effect on agriculture, environment and human health. In plant, it inhibit growth, interfere with important cellular processes such as photosynthesis and respiration Prasad and Strzalka, (2002), cause oxidative stress in plants and has many other hazard effects García et al. (1999) Humic acids and their derivatives can be used for removing toxic metals and their ion from wastewater and lowers the concentrations of undesirable ions below the permissible limit and in soil remediation at contaminated sites as washing agents for cleaning heavy metal polluted soils Rebhun et al. (1998). It was indicated that humate can enhance removal of phenols, oils and copper in biological system. They also can support growth of the biomass as carbon source and stimulating growth agent Kim et al. (1990).

Various authors showed that the
characteristics of humic acids depend on the parent material they are extracted from (Rice and Mac Carthy 1991 and Lobartini et al. 1992) and on the method of extraction, (Yamamoto et al. 1994and Makarov 1999).

In addition to the above facts, humus regulate the biological activity and fertility of soils (Chouliaras et al. 1998 and Gougoulias et al. 2010). They exert antiviral activities against various DNA as well as RNA viruses. Scientific studies have documented the antiviral effects of humic acid against a multitude of viruses including and influenza, hepatitis, herpes simplex, HIV-1, West Nile, retroviruses, and hemorrahagic fever. Specific properties of humic acid products enable their application in industry, agriculture, environmental and biomedicine Eladia et. al. (2005) .So They are powerful biologic materials, that will soon Play major role in fixing many environmental problems.

On other hand, very important amounts of olive mill waste are produced in olive cultivation areas. The profitable use of these organic materials are beneficial both to economical value as renewable resources and environmental protection.

According to the statistics of the Egyptian Ministry of Agriculture (2001), the cultivated area of olive trees about 113.080 thousand acres and the average production per acre of 3.8 tons. The pressing of $100 \mathrm{~kg}$ of olives (with added water during process extraction) produces on average 60 $\mathrm{kg}$ of olive solid waste and 100 to $240 \mathrm{~kg}$ of olive mill waste water. These wastes are important source of pollution owing to its relatively high content of organic matter The disposal of these wastes leads to serious environmental problems in olive oil producing areas. The potentially toxic attributes also to the intense of short time interval of production which increases the environmental hazards. In Egypt, olive wastes as other agriculture wastes enormous wealth yet to be exploited.

Composting has been shown to be a suitable method for recycling agriculture wastes, where these organic wastes can be converted into humus, in a matter of a few weeks or months. The naturally occurring microorganisms such as bacteria and fungi, small invertebrates, such as earthworms and millipedes, help to complete the composting process. The produced humus consists of partly decomposed organic materials and newly formed humic like and fulvic like acids. There are many procedures used in composting olive mill solid wastes (Madej et al., 1998; Paredes et al., 2000 and Negro and Solano, 1996). The composting process requires adequate conditions of $\mathrm{pH}$, temperature, moisture, oxygenation and nutrients, to allow the adequate development of the microbial population De Bertoldi (1992). Therefore, changes in these conditions during the process will affect the proliferation of certain microflora, having different enzymatic activities which control the OM degradation. So the quality of humic acids can be greatly affected. Also, some degrees of differences are observed in the physical and structural properties of HA, if geographical origin differs. Barot and Bagla (2009).

It was concluded that humic acids studies are essential for a healthy and productive soil. So, without agriculture learning to accept the use of "qualified and quantified" humic acids, an 
essential part of the equation of the biological management plant of soil, food security with our booming population growth will become impossible,

This work aimed to compost solid olive waste without supporting with any plant residues, no additives under uncontrolled atmospheric conditions, followed by extraction and purification of humic acids from these composite, then determine their chemical and spectroscopic characteristics, evaluate their complexing sites contents and their chelating ability for copper ions. This is to introduce the humic acids for studying the possibility of using in treatment of soil and irrigation water in olive cultivation to increase crop production and other environmental applications.

\section{Material and methods}

All chemicals used during the investigation were analytical or laboratory grade reagents. Distilled water was used for the whole experiments. A four decimal OHAUS analytical balance, was used. Experiments are made in doublets. Metal ions Solutions was standardized by atomic absorption measurements. Correction for background $\mathrm{Cu}^{+2}$ ion was taken into consideration.

Sampling and Composting : Four solid wastes are taken from two different factories in Cairo Egypt. Sample (I) was in form of compact and moist, sphere of about $20 \mathrm{~cm}$ diameter. It was stored indoor in black plastic bag. Samples II, III, and IV were containing high percentage of water each was about $50 \mathrm{~kg}$ and stored indoor, outdoor in closed plastic bucket and in direct sun light, respectively for time intervals of 1-2 years. Humic acids extraction and purification: Humic acids( HAI, HAII, HAIII, and HAIV are extracted from the composts I,II,III, and IV respectively. The extraction and purification procedure were according to the method developed by the International Humic Substances society (IHSS) which is considered as an acceptable method for the extraction of humic substances from soil Swift (1996) with modification includes the extraction for 6 hours. The precipitated humic acids washed till negative $\mathrm{Cl}^{-}$test then freezed, humic acid particles were filtered under suction, and then dried in air and kept in desiccators at room temperature.

\section{Humic acids Analysis:}

Elemental analysis $\mathrm{C}, \mathrm{H}$,and, $\mathrm{N}$ percents were determined for each humic acids on the Elemental Aero EL 111Analyzer. The final percentages were calculated on dry ash free base. The oxygen content $(\% \mathrm{O})$ strictly speacking (Oand $\mathrm{S}$ ) was calculated by the difference: $\mathrm{O}=100 \%-(\mathrm{C}+\mathrm{H}+$ $\mathrm{N})$. The Atomic ratio were calculated on dry ash free base, The degree of internal oxidation $(\omega)$ were calculated according to Maris et al. (2013) by the equation: $\omega=(2 \mathrm{O}+3 \mathrm{~N}-\mathrm{H}) / \mathrm{C}$ where: $\mathrm{O}, \mathrm{N}$, $\mathrm{H}$, and $\mathrm{C}-$ are the elemental composition, in atom percentage.

Chemical analysis: Moisture content was measured by drying weighed samples at $105^{\circ} \mathrm{C}$ for 24 hours. Ash contents was measured by ignition in a muffle furnace at $700^{\circ} \mathrm{C}$ for $4 \mathrm{hrs}$, (Black 1965 and Schnitzer 1982).

Complexing sites: The phenolic and carboxylic groups are the most responsible for the development of the $\mathrm{pH}$ - dependent electron negative charge which have the ability to bind metal cations. The content of $\mathrm{COOH}$ and Phenolic hydroxyl groups is called the total acidity and is determined by the baryta method, while the carboxylic acidity is determined by the $\mathrm{Ca}$-acetate method. The concentration of phenolic groups is calculated as the difference between total and carboxylic acidity the practical procedures were conducted according to Schnitzer and Umesh (1965)

Ultraviolet-Visible spectra: were carried out on potassium humates solution between 190-1100 nm on Perkin Elmer,Precisely Lambada 45,UV/VIS Spectrometer. Humate solution was prepared by dissolving $0.02 \mathrm{~g}$ of purified humic acids in $5 \mathrm{ml}$ of $0.1 \mathrm{~N} \mathrm{KOH}$ solution under $\mathrm{N}_{2}$ the $\mathrm{pH}$ was adjusted to 7 by adding $0.1 \mathrm{~N} \mathrm{HCl} . \mathrm{KCl}$ solution was added to attain $0.20 \mathrm{M}$ in $25 \mathrm{ml}$. A blank was set up under the same condition Theng et al. (1967).

Chromaticity Coefficient (E4/E6 ratio) The absorbencies of the above solutions at $400 \mathrm{~nm}$ (E4) and at $600 \mathrm{~nm}(\mathrm{E} 6)$ were recorded. The ratios of the two absorbance $\left(\mathrm{E}_{4} / \mathrm{E}_{6}\right)$ were calculated for the four humic acids Iheoma et al.(2007)

FT-IR Spectra These spectra for the isolated humic acids were recorded over a wave number range $400-4000 \mathrm{~cm}^{-1}$ on a Jasco FTIR 460 plus spectrometer ( $\mathrm{KBr}$ technique) where the samples were prepared by grinding the solid compound 
with anhydrous potassium bromide, then pressed into the form of a disc for convenient sampling.

\section{Metal-Humic Acid Complexation Reactions}

In order to study the complexing ability of humic acids (HAI ), an aqueous solution of HAI was prepared, by dissolving $0.25 \mathrm{~g}$ of the solid in of $0.05 \mathrm{M} \mathrm{NaOH}$. The $\mathrm{pH}$ adjusted to7 with nitric acid and $\mathrm{NaOH}$ and the volume was completed to $250 \mathrm{ml}$. the concentration of this solution equals to $7.31 \mathrm{meq} / \mathrm{l}$ of ionizable $\mathrm{H}^{+}$ions. A blank was set up in the same manner. Stock solutions of analytical grade purity $\mathrm{CuSO}_{4} .5 \mathrm{H}_{2} \mathrm{O}$ was prepared $\left(0.2 \mathrm{M} \mathrm{CuSO}_{4}\right)$. Two series were set up at the same conditions. In the first series (A) (represent the metal after complexation) various concentrations of $\mathrm{Cu}^{+2}$ were injected into $10.0 \mathrm{~mL}$ humic acid solution $\left(1.462 \mathrm{meq} / \mathrm{L} \mathrm{H}^{+}\right.$ions $)$The volume in each bottle was completed to $50 \mathrm{ml}$ to attain the concentrations $73,165,365,625,1380 \mathrm{mg} / \mathrm{LCu}^{+2}$. . The second series (B) was set up in the same condition with absence of humic acid. The solutions were mixed and allowed to stand. Following adequate time for reaction and settling of copper humates, the supernatants were centrifuged for five minutes at $5000 \mathrm{rpm}$ and removed. $\mathrm{pH}$, conductivity, copper concentrations of the supernatants were measured with the $\mathrm{pH}$ meter(Hanna 210), Conductometer (EYLA), Atomic Absorption Spectrophotometer (AA Analyst 800,Perkin Elmer, USA) respectively. The FTIR spectra of a precipitate is recorded over a wave number range $400-4000 \mathrm{~cm}^{-1}$ on the Jasco FTIR 460 plus spectrometer.

\section{HAI solution for the biological tests}

$0.1 \mathrm{~g}$ of HAI was dissolved in a minimum amount of $0.05 \mathrm{NaOH}$. The $\mathrm{pH}$ was adjusted to 6-7 by 0.1 $\mathrm{N} \mathrm{HCl}$ and the volume was completed to $100 \mathrm{ml}$.

\section{Biological Evaluation}

Antimicrobial activity Assay The preliminary antimicrobial activity was investigated on the humic acid. All microbial strains were provided from culture collection of the Regional Center for Mycology and Biotechnology (RCMB), Al-Azhar University, Cairo, Egypt. The antimicrobial profile was tested against two Gram-positive bacterial species (Bacillus subtilis, Staphylococcus aureus), two Gram negative bacterial species (Escherichia coli, Pseudomonas aeruginosa), on three fungi ( penicillium italicum ,Geotrichum candidum and Aspergillus funigtus using a modified well diffusion method (Klančnik et al., 2010).

Antitumor activity assay: Human breast carcinoma (MCF-7), colon adenocarcinoma (HCT-116), cervical carcinoma (HeLa), hepatocellular carcinoma (HepG2), prostate carcinoma (PC-3), and lung adenocarcinoma (A549) cell lines were obtained from the American Type Culture Collection (ATCC, Rockville, MD). The cells were grown on RPMI-1640 medium supplemented with $10 \%$ inactivated fetal calf serum and $50 \mu \mathrm{g} / \mathrm{ml}$ gentamycin. The cells were maintained at $37^{\circ} \mathrm{C}$ in a humidified atmosphere with $5 \% \mathrm{CO}_{2}$ and were subcultured two to three times a week. For antitumor assays, the work was conducted according to (Mosmann, 1983; Elaasser et al., 2011).

Antioxidant activity assay: The antioxidant activity of extract or purified compound (s) was determined at the Regional Center for Mycology and Biotechnology (RCMB) at AlAzhar University by the DPPH free radical scavenging assay in triplicate and average values were considered. The work was conducted according to $\mathrm{Xi}$ and Schaich, (2014)

Antiviral activity assay: The screening antiviral assay system using cytopathic effect inhibition assay at the Regional Center for Mycology and Biotechnology (RCMB) at AlAzhar University. This assay was selected to show specific inhibition of a biologic function, i.e., cytopathic effect (CPE) in susceptible mammalian cells according to Vijayan et al., (2004)

\section{Results and discussion}

Humic acids analysis: Elemental analysis: The atomic ratio, H/C: N/C: O/C can be used to identify the type of humic acids source (Alken et al. 1985 ${ }^{40}$; Kim 1998 ${ }^{41}$; Polak and Sułkowski 2006). Also, the atomic ratios $\mathrm{C} / \mathrm{N}, \mathrm{H} / \mathrm{C}$ and $\mathrm{O} / \mathrm{C}$ for soil humic acids give indications about the humic acids nature: $\mathrm{C} / \mathrm{N}$ (of range 10.1 to 30 ) is an index of organic material maturity. $\mathrm{H} / \mathrm{C}$ is a measure of aromatization and condensation (Larger for aliphatic, lower for aromatic and high content of free radical). O/C (of range 0.36-0.68) reflects the increase of oxygen functional groups, 
(carboxlic), (Sparks 199943, Gabbour and Daves 2001 Polak and Sułkowski, 2006). Table (1) shows the ash content, chromaticity ratios and the properties based on the elemental analysis, of humic acids HAI, HAII, HAIII and HAIV extracted from composts, I,II, III, and IV respectively, in comparison with that of HAsoil and $\mathrm{HA}_{\mathrm{T} 12}$ extracted from an Egyptian soil and composted olive cake which supported with straw and olive mill waste water after one year respectively. Also, compared with, $\mathrm{HA}_{\mathrm{L} \text { Soil R }}$, the average elemental analysis of 410 samples extracted from different environments all over the world which were compiled from the literature by James and MacCarthy (1991).

Table ( 1 ) Elemntal characteristics of humic acids extracted from composted olive cake under different atmospheric condition ( on dry ash free base)

\begin{tabular}{|c|c|c|c|c|c|c|c|c|c|c|c|c|}
\hline \multirow{2}{*}{ HA } & \multicolumn{6}{|c|}{$\%$} & \multicolumn{4}{|c|}{ Atomic ratios } & \multirow{2}{*}{$\mathrm{E}_{4} / \mathrm{E}_{6}$} & \multirow{2}{*}{$\begin{array}{c}\text { Empirical } \\
\text { formula }\end{array}$} \\
\hline & $\omega$ & Ash & $\mathrm{C}$ & $\mathrm{H}$ & $\mathrm{N}$ & $\mathrm{O}$ & $\mathrm{C} / \mathrm{N}$ & $\mathrm{H} / \mathrm{C}$ & $\mathrm{O} / \mathrm{C}$ & $\mathrm{N} / \mathrm{C}$ & & \\
\hline HAI & -1.5 & 0.39 & 60.70 & 11.70 & 3.28 & 24.32 & 21.59 & 2.30 & 0.30 & 0.05 & 6.04 & $\mathrm{C}_{22} \mathrm{H}_{50} \mathrm{O}_{7} \mathrm{~N}$ \\
\hline HAII & -3.22 & 1.05 & 67.00 & 19.42 & 2.64 & 10.94 & 29.61 & 3.48 & 0.12 & 0.04 & 4.91 & $\mathrm{C}_{27} \mathrm{H}_{92} \mathrm{ON}$ \\
\hline HAIII & -3.86 & 0.67 & 69.76 & 22.93 & 2.90 & 4.41 & 28.06 & 3.94 & 0.05 & 0.04 & 4.34 & $\mathrm{C}_{28} \mathrm{H}_{111} \mathrm{ON}$ \\
\hline HAIV & -3.11 & 0.89 & 88.16 & 23.47 & 2.10 & 1.27 & 48.98 & 3.20 & 0.01 & 0.02 & 4.34 & $\begin{array}{c}\mathrm{C}_{105} \mathrm{H}_{335} \mathrm{O} \\
\mathrm{N}_{2}\end{array}$ \\
\hline HAsoil & -1.00 & 0.00 & 47.00 & 5.78 & 3.09 & 44.13 & 17.75 & 1.48 & 0.70 & 0.06 & 5.29 & $\mathrm{C}_{18} \mathrm{H}_{26} \mathrm{O}_{3} \mathrm{~N}$ \\
\hline HALSoilR & - & - & $\begin{array}{c}37.18- \\
64.1\end{array}$ & $\begin{array}{c}1.64- \\
8.0\end{array}$ & $\begin{array}{c}0.5- \\
7.0\end{array}$ & $\begin{array}{l}27.1- \\
51.98\end{array}$ & - & $\begin{array}{c}0.08- \\
1.77\end{array}$ & $\begin{array}{c}0.33- \\
0.98\end{array}$ & - & - & - \\
\hline $\mathrm{HA}_{\mathrm{T} 12}$ & 0.071 & 11.94 & 43.13 & 5.15 & 3.6 & 36.18 & 20.50 & 1.43 & 0.5 & 0.06 & 8.00 & $\mathrm{C}_{14} \mathrm{H}_{20} \mathrm{O}_{9} \mathrm{~N}$ \\
\hline
\end{tabular}

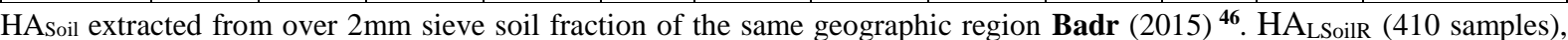
from environments all over the world were compiled from the literature, James and Maccarthy (1991) HAT12: HA extracted from composted olive cake which supported with straw and olive mill waste water after one year Ghita, et al.(2003).

It is noted that levels of $\mathrm{C}$ and $\mathrm{H}$ decreased while level of $\mathrm{O}$ increased and $\mathrm{N}$ remained more or less constant, when comparing, HAI with HAII, HAIII and HAIV which means that composting progressed well in compost $\mathrm{I}$, So, the $\mathrm{C} / \mathrm{N}$ ratio decreased while $\mathrm{O} / \mathrm{C}$ ratio and the internal oxidation parameter, $\omega$, increased. The higher the value of the $\mathrm{O} / \mathrm{C}$ ratio, the higher $\omega$, the higher the degree of humification and oxidation of humic matter Debska et al. (2012) While the elemental composition of HAII. HAIII, and HAIV are very far from the literature soil range (HA $\left.{ }_{\text {LsoilR }}\right)$, the elemental composition of HAI lies within the range with hydrogen exception. Also, the atomic ratios $\mathrm{H} / \mathrm{C}$ : $\mathrm{O} / \mathrm{C}$ : N/C-which determine humic acids source for $\mathrm{HAI}$ and $\mathrm{HA}_{\mathrm{T} 12}$ are not completely identical due to high $\mathrm{H}$ content HAI and mixed source of $\mathrm{HA}_{\mathrm{T} 12}$.

The positive values of degree of internal oxidation are characteristic for soil with aerobic conditions. HAI, HAII, HAIII, HAIV show negative degrees of internal oxidation, confirming anaerobic conditions prevailing during diagenetic transformation. Accordingly HAI, HAII, HAIII and HAIV, are in their reduced form Orlov (1985), which is the case as artificially humic acids. However, HAI is the most oxidized i.e, it expected to have the highest carboxylic groups in comparison with HAII, HAIII and HAIV. Considering the condition of compost I, and in accordance with Kim (2014), the well drained soil, which is under good aerobic condition can affect humic matter oxidations, it can be reported that solid olive waste with good humidity and under good aerobic condition can affect humic matter oxidation.

$\mathbf{E}_{\mathbf{4}} / \mathbf{E}_{\mathbf{6}}$ : is an indicator of the degree of humification. A high ratio infers a low molecular weight and a greater level of aliphaticity. A low ratio however indicates a higher molecular weight with greater level of condensation or aromaticity. Sim Siong et al. (2007). $\mathrm{E}_{4} / \mathrm{E}_{6}$ of HAI can not be compared with HAII, HAIII, and HAIV as their elemental properties lies far outside the humic acids range. However the molecular weight order can be arranged as: HASoil >HAI > HAT12.

The van Krevelen diagram is suited to differentiate humic substances. This diagram confirm that some preferred composition, or a relatively narrow range of compositions, exists for HS in nature James and Mac Carthy(1991).The diagram is used here to determine the position of HAI in relation to humic acids a from different environments which were studied by other workers. As shown in Fig ( $1 \mathrm{a}, \mathrm{b}) \mathrm{HAI}$ tend to occupy the region with higher $\mathrm{H} / \mathrm{C}$ and lower $\mathrm{O} / \mathrm{C}$ values. This position of HAI approaches the border range of HAs in thermal waters which are characterized by higher aromaticity and depletion in oxygen than usually experienced for humic materials in soil and fresh water Kovács et al. (2012). 


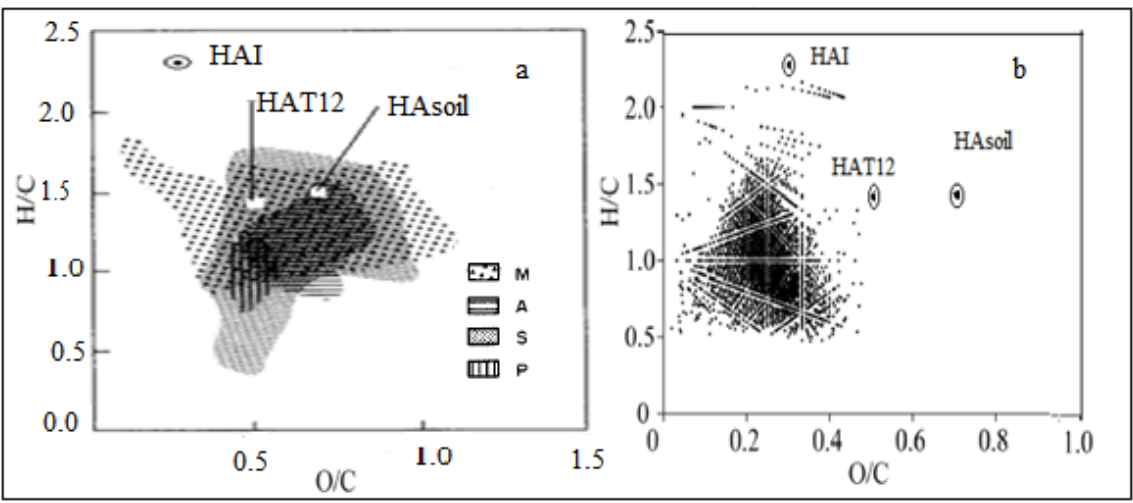

Fig. 1. The positions of HAI, HAT12 and HAsoil on van Krevelen diagrams of humic acids (a) : based on soil humic acids, 215 samples, S, fresh water, 56 samples, A, ,marine sediment, M, and peat, 23 samples, P, (b): humic acids isolated from thermal waters at depths of 993 and $2103 \mathrm{~m}$ \{the diagram (a) and (b) according to James and Mac Carthy (1991) and Kovács et al. (2012) respectively.

\section{FTIR and UV-VIS Spectra}

Fig (2),(3) and(4) show the FTIR spectra of HAI, HAII, HAIII, HAIV; FTIR spectra of HAI in comparison with some literature selected humic acids spectra; and uv-vis spectra of the four studied humic acids respectively. Table (2) gives the attributions of the main infra-red peaks shown by the four acids. Table ( 3 ) gives Infrared and UV-vis absorbance values belonging to wave numbers $1620 \mathrm{~cm}^{-1}, 2926 \mathrm{~cm}^{-1}$ wave number and $240 \mathrm{~nm}$ wave length respectively, compared with the degree of internal oxidation $\omega$ given in Table(1)

Not all possible assignments for specific infra-red bands are given because the absorptions overlap. The fingerprint region (below $1300 \mathrm{~cm}^{-1}$ ) characterized by variety of combination bands which are strengthen and fused from one humic acid to anther giving a more simple spectra in case of HAI spectrum. A comparison of the infra-red spectra of the humic acids from the different composting conditions shows that the spectra are qualitatively similar. The band attributions given in Table (1) indicating all characteristic features for soil humic acid as shown in literatures e.g Alken et al. (1985)

According to the band assignments given in Table(2), the changes due to the chemical modifications occurring during the different composting conditions can be explained as following:

- absorbance at wave number of $1710 \mathrm{~cm}^{-1}$ is the highest in all cases, .indicating that the acids are reasonably enriched in carboxyl groups which especially highest in HAI.

- the intensity increase of bands at $3403-3383 \mathrm{~cm}^{-}$ ${ }^{1}$ and $1655-1638 \mathrm{~cm}^{-1}$ with simultaneous strongly decrease of the bands at 2925, 2850, reflecting a reduction of the aliphatic content, increase in condensation the (aromatic contents) and oxygencontaining functional groups -especially in case of HAI-

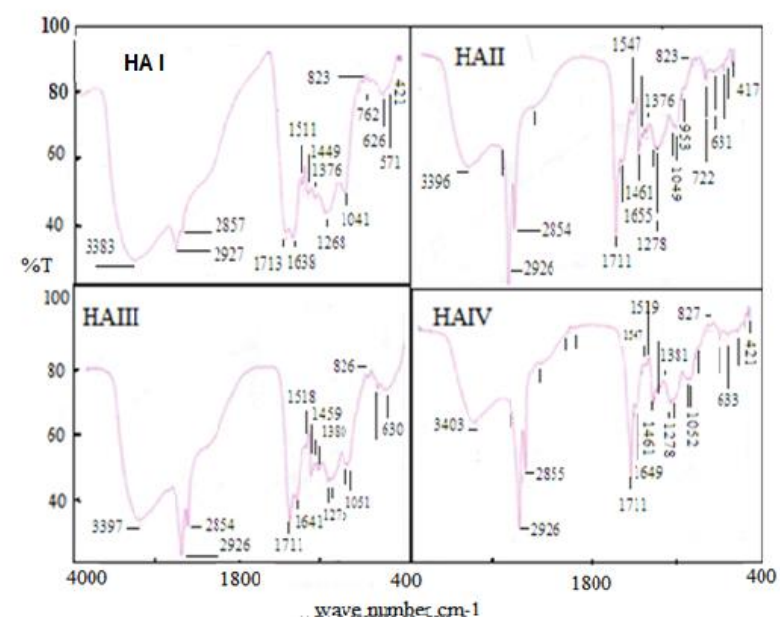

Fig (2). FTIR spectra of four humic acids extracted by $0.1 \mathrm{~N} \mathrm{NaOH}$ and 6 hrs extraction time from olive mill solid waste composted under four different atmospheric conditions for about 18 month . 
Table ( 2 ). Attributions of main infra-red peaks of the humic acids extracted from composted olive mill solid wastes under different conditions. (Jlkovic e t al.. 2001 ; Naidja et al. 2002 Iheoma et al., 2007; Erdogan et al., 2007 ; Giovanela et al.,2010 Peruma et al. ; 2013)

\begin{tabular}{|c|c|}
\hline$-v \mathbf{c m}^{-1}$ & assignments \\
\hline $3404-3383$ & $\begin{array}{l}\text { Broad and strong band of stretching of alcoholic and phenolic hroydroxyl groups, } \\
\text { intra molecular H.bondig and probably including those of } \mathrm{COOH} \text { and } \mathrm{N}-\mathrm{H}\end{array}$ \\
\hline 2927 & Aliphatic $\mathrm{CH}$ stretch of $\mathrm{CH}_{2}$ and $\mathrm{CH}_{3}$ also $\mathrm{CH}_{2}-\mathrm{C}=\mathrm{C}-$ in aliphatic or aromatic \\
\hline 2857 & the aliphatic bands $\mathrm{C}-\mathrm{H}$ \\
\hline 1713 & the $\mathrm{C}=\mathrm{O}$ stretching vibrations due to protonated carboxylic groups \\
\hline $1654-1636$ & $\begin{array}{l}\mathrm{C}=\mathrm{O} \text { stretch, amid } \mathrm{I} \text {, quinones and aromatic } \mathrm{C}=\mathrm{C} \text { or/and 1-keto-2 hydroxy or } \\
\text { amino aryl ketones }\end{array}$ \\
\hline $1540-1512$ & $\begin{array}{l}\text { primary amine- } \mathrm{NH}^{+}-\text {, symmetric } \mathrm{NH}_{3} \text { deformation and } \mathrm{C}=\mathrm{N} \text { stretch amide II- } \\
\text { aromatic } \mathrm{C}=\mathrm{C} \text { viberation, } \mathrm{C}-\mathrm{N} \text { bend } \mathrm{C}-\mathrm{CH}_{3}\end{array}$ \\
\hline $1461-1449$ & $\mathrm{C}-\mathrm{CH}_{3}$ \\
\hline $1376-1380$ & $\begin{array}{l}\text { B-O stretch (1380-1310), Tertially butyle group (1374-1366), in plane bend of } \\
\text { phenolic OH }\end{array}$ \\
\hline 1268 & $\begin{array}{l}\text { correspond to COO- and to C-O The former peak indicates that part of the humic } \\
\text { acid could exist also in the sodium form. }\end{array}$ \\
\hline 1041 & ortho substitution, C-C-O of primary alcohol \\
\hline 823 & $\begin{array}{l}\text { out plane vibration of isolated } \mathrm{C}-\mathrm{H} \text { group found in bituminous brown coal also } \\
\text { due to cis cyclic ether, expoxy compound }\end{array}$ \\
\hline$(<1000)$ & substituted aromatic rings \\
\hline
\end{tabular}
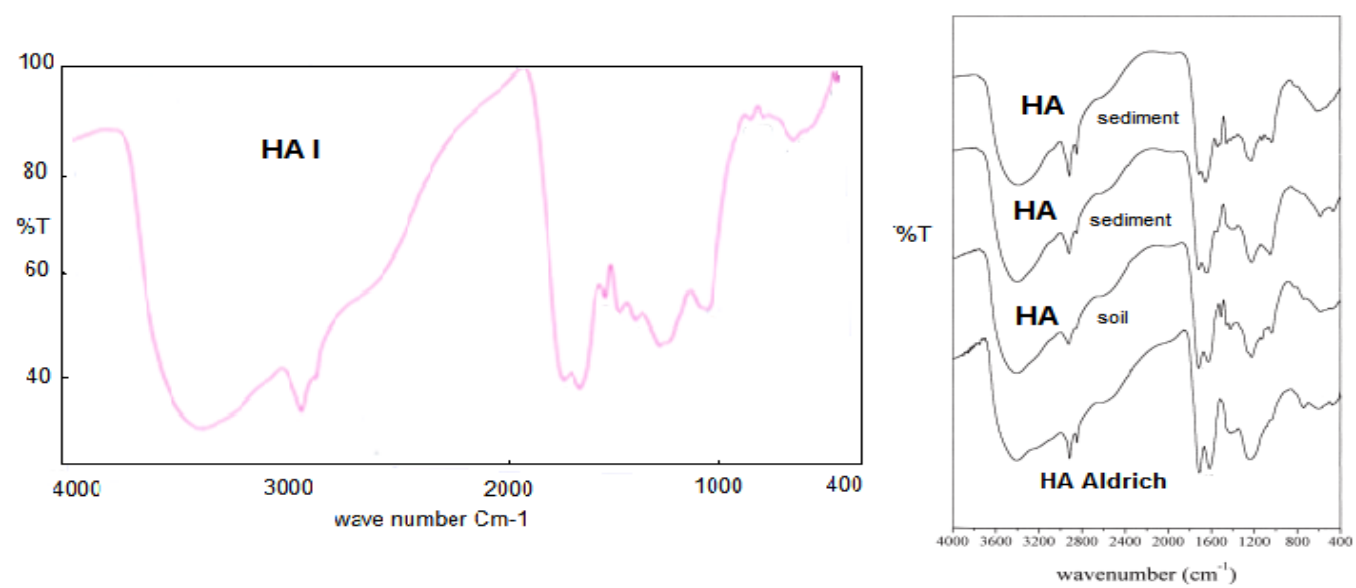

Fig (3): FTIR spectra of HAI in comparison with two sediment, one soil and Aldrich humic acids according to Giovanela et al.(2004)

Similar results were reported, (Ghita, et al 2003and Senesi et al.2007). In comparison of HAI FTIR with selected spectra in Fig (3), it is noted that HAI spectra similar to soil and sediment HA, but similar to Aldrich HA in the region from $4000 \mathrm{~cm}^{-1}$ to $2000 \mathrm{~cm}^{-1}$ which may due to strengthen and broadening of the band at $3383 \mathrm{~cm}^{-1}$ indicating higher content of alcoholic and phenolic hroydroxyl groups, intra molecular H- bonding probably including those of $\mathrm{COOH}$ and $\mathrm{N}-\mathrm{H}$.

The UV-vis spectra of the humic acids solutions were recorded from $190 \mathrm{~nm}$ to $1100 \mathrm{~nm}$. The four
Humic acid give absorption spectra with absorption increasing at lower wavelengths as the case with natural humic acids (Kim 1998 ; Giovanelaa.et al 2010Barison et al. 2010). The four spectra show humps at about $280 \mathrm{~nm}$ and maxima at $208 \mathrm{~nm}$. regions This is similar with the UV-vis spectra of humic acids previously extracted from soil, Nile water hyacinth, sewage sludge, and cattle manure composites(Badr, 2003 and Ebtehar, 2011). These similarities may due to the same climate conditions, as it was confirmed by others Helena et al, (1994) 


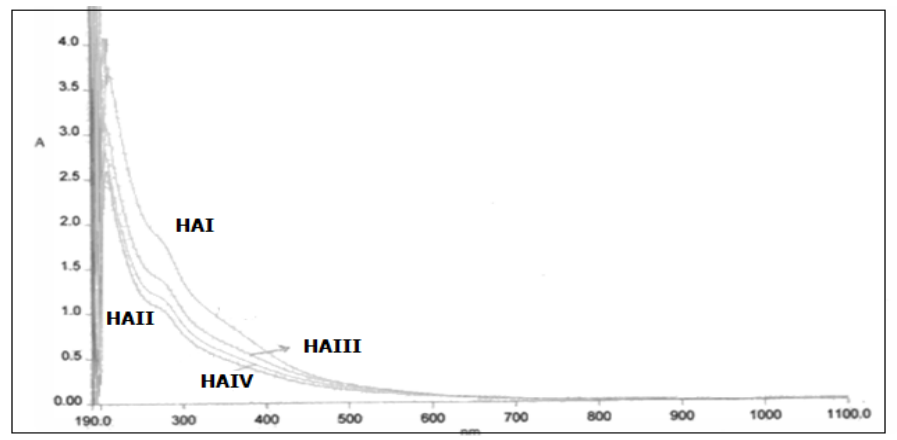

Fig. 4: Uv-Vis spectra of four humic acids extracted by $0.1 \mathrm{~N} \mathrm{NaOH}$ and 6 hrs extraction time from olive mill solid waste composted for about 18 month under four different atmospheric conditions. (Concentration $=200 \mathrm{mg} / \mathrm{L}$ in $0.2 \mathrm{KCl}, \mathrm{pH}=7$ )

Table (3) Infrared and UV-vis absorbance values belonging to wave numbers $2925 \mathrm{~cm}^{-1}$, $1620 \mathrm{~cm}^{-1}$ and $254 \mathrm{~nm}$ respectively compared with the degree of internal oxidation $\omega$

\begin{tabular}{|c|c|c|c|c|c|}
\hline HAs & $\mathbf{A}_{\text {240nm }}$ & $\begin{array}{c}\mathbf{A 2 9 2 5 c m}^{-1} \\
\text { aliphatic }\end{array}$ & $\begin{array}{c}\mathbf{A 1 6 2 0 c m}^{-1} \\
\text { aromatic }\end{array}$ & $\begin{array}{c}\text { aromatic } \\
\text { aliphatic }\end{array}$ & $\boldsymbol{\omega}$ \\
\hline HAI & 2.05 & 0.489 & 0.444 & 0.933 & -1.5 \\
\hline HAII & 1.18 & 0.294 & 0.116 & 0.395 & -3.22 \\
\hline III & 1.52 & 0.498 & 0.308 & 0.618 & -3.86 \\
\hline IV & 1.31 & 0.268 & 0.107 & 0.399 & -3.11 \\
\hline
\end{tabular}

The four spectra differed in the optical densities, absorbance, at $254 \mathrm{~nm}$ in the order HAI> HAIII> HAIV> HAII which indicate increasing in the concentration of the absorbing moieties in this order. Also UV-absorbance at $254 \mathrm{~nm}$, has been shown to increase with increasing molecular weight, degree of condensation, and the ratio of aromatic to aliphatic moieties. Table ( 3 ) shows the aromatic / aliphatic ratios calculated from absorbance at $2925 \mathrm{~cm}^{-1}$ and $1620 \mathrm{~cm}^{-1}$ according to Lis et al. (2005). From these results, it is observed that the order of increasing the aromatic / aliphatic ratios parallel to the order of increasing absorbance at $254 \mathrm{~nm}$. This reported by Stevenson (1994). Accordingly HAI extracted from compost I is the highest humified and characterized by highest carboxylic groups as confirmed by elemental analysis.

\section{Chemical evaluation of complexing sites}

Table (4) presents the acidic functional groups contents of the extracted humic acids as determined by barium hydroxide and calcium acetate methods. The carboxyl contents of HAIII and HAIV cannot be determined because of their high buffering capacity at the $\mathrm{pH}$ of the titration end point in case of the calcium acetate procedure. It is noted that, the condition of compost I, which permit to the highest oxidation and condensation resulted in the highest total acidity of HAI, which confirm the results elemental and spectroscopic analysis. Total acidity of HAI approaches the higher values within the total acidity range of soil humic acids means that HAI has a high ability to bind positively charged ions.

Table (4) Total acidity (T.A.), contents of $\mathrm{COOH}$ and $\mathrm{OH}$ groups of the four extracted humic acids

\begin{tabular}{|c|c|c|c|c|}
\hline \multirow{2}{*}{ HA } & \multirow{2}{*}{$\mathbf{H}_{\mathbf{2}} \mathbf{O} \%$} & \multicolumn{3}{|c|}{ Functional group in meq/ g } \\
\cline { 3 - 5 } & & T.A. & $\mathbf{C O O H}$ & $\mathbf{O H}$ \\
\hline HA $_{\mathrm{I}}$ & 9.03 & 7.31 & 3.11 & 4.20 \\
\hline HAII & 8.12 & 2.81 & 1.87 & 0.94 \\
\hline HAIII & 8.89 & 1.73 & - & - \\
\hline HAIV & 10.95 & 2.43 & - & - \\
\hline Soil Ref. range & -- & $5.5-8.3$ & $2.4-3.9$ & $2.8-4.4$ \\
\hline
\end{tabular}

Interaction between $\mathrm{Cu}(\mathrm{II})$ and olive cake humic acids

Table (5) shows the results of complexation reactions of HAI under the effect of varying copper ion concentration. Fig (5) shows the FTIR spectra of HAI- $\mathrm{Cu}$ humate complex. It is observed that at the concentration of copper $73 \mathrm{mg} / \mathrm{L}$, the $\mathrm{pH}$ of the solution was 4.66 and the conductance of the solution was $39.4 \mathrm{mS} / \mathrm{cm}$. However, after complex formation, the concentration of copper in the supernatant was reduced to $57 \mathrm{mg} / \mathrm{L}$. 
Moreover, the $\mathrm{pH}$ of the supernatant solution became 5.63 and the conductivity was also increasing to $166.4 \mathrm{mS} / \mathrm{cm}$. These changes occur systematically with increasing copper ions. This implies that the complex formation between $\mathrm{Cu}$ (II) and humic acid was occurred at the slightly acidic solution. These results are in agreement with results obtained for reaction of $\mathrm{Fe}$ (III) with humic acid of the Buriganga River, Mohammad et al. (2010). The increase of conductivity observed can be attributed to liberation of $\mathrm{Na}^{+}$ions from humate molecules because the mobility of $\mathrm{Na}^{+}$ ions is much higher than any other molecule in the system.
FTIR analysis of HAI - $\mathrm{Cu}$ humate complex showed changes in the phenolic -OH related peaks $\left(3383 \mathrm{~cm}^{-1}\right)$, the acid related peaks 1713,1638 and $1265 \mathrm{~cm}^{-1}$ and the amide related peaks in the region $1511 \mathrm{~cm}^{-1}$. The strengthening of the peak at $3383 \mathrm{~cm}^{-1}$, with the remaining of the band at $1376 \mathrm{~cm}^{-1}$ suggest that the phenolic $\mathrm{OH}$ not participate in $\mathrm{Cu}$ chelation by HAI. The complete disappearance of the bands at 1713, 1265 and1511 $\mathrm{cm}^{-1}$ and weakening at $1638 \mathrm{~cm}^{-1}$ suggested a Cu$\mathrm{N}$ coordination and an extensive decarboxylation in the humic acid structure.

Table ( 5) Variation of $\mathrm{pH}$ and conductivity with the change of concentration of Copper (II) in HAI solution(1.452meq/l).

\begin{tabular}{|c|c|c|c|c|c|c|}
\hline \multicolumn{2}{|c|}{ Before complexation } & \multicolumn{4}{|c|}{ After complexation } \\
\hline $\begin{array}{c}\text { Concentration } \\
\text { Of Cu(II) } \\
\text { Solution } \\
\text { (mg/L) }\end{array}$ & $\mathbf{p H}$ & $\begin{array}{c}\text { Conductivity } \\
\text { (mS/cm) }\end{array}$ & $\begin{array}{c}\text { Concentration } \\
\text { Of Cu(II) in } \\
\text { supernatant } \\
\text { (mg/L) }\end{array}$ & $\mathbf{p H}$ & $\begin{array}{c}\text { Conductivity } \\
\text { (mS/cm) }\end{array}$ & $\begin{array}{c}\text { complexed Cu ions } \\
\text { in mg/L }\end{array}$ \\
\hline 73 & 4.66 & 039.4 & 57.0 & 5.63 & 166.4 & 16 \\
165 & 4.33 & 070.2 & 140 & 5.46 & 196.2 & 25 \\
365 & 4.04 & 120.1 & 317 & 5.20 & 240.0 & 48 \\
625 & 3.77 & 205.0 & 565 & 4,74 & 319.0 & 60 \\
1380 & 3.47 & 352.0 & 1370 & 3.70 & 472.0 & 10 \\
\hline
\end{tabular}

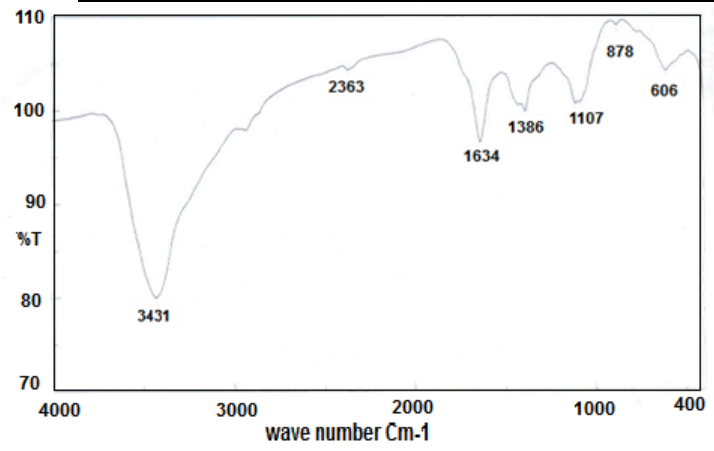

Fig. 5 FTIR spectra of HAI-Cu chelate

Determination of conditional stability constant $\beta$ for the $\mathrm{Cu}(\mathrm{II})$ humate complex

. The interaction of the $\mathrm{Cu}$ (II) ion with humic acid can be written as

$\mathrm{HAI}+\mathrm{Cu}^{+2}{ }_{(\mathrm{aq})} \leftrightarrow \mathrm{CuHAI}$

the conditional stability constant $\beta$ for the $\mathrm{Cu}$ (II) humate complex is given by

$\beta=\frac{[\mathrm{CuHAI}]}{\left[\mathrm{Cu}^{2+}\right]_{\text {free }}[\mathrm{HAI}]_{\text {free }}}$

Where [CuHAI] is the concentration of the complexed $\mathrm{Cu}(\mathrm{II})$ ion, and equals to the total $\mathrm{Cu}$ (II) ion concentration (initial $\mathrm{Cu}$ (II) ion concentration) minus the non-complexed $\mathrm{Cu}$ (II) ion, $\left[\mathrm{Cu}^{+2}\right]_{\text {free }}$, since hydrolysis of the $\mathrm{Cu}$ (II) ion at slightly acidic $\mathrm{pH}$ is negligible. [HA(I)]free is defined as the concentration of active sites available for $\mathrm{Cu}$ (II) ion complexation and is calculated according to

$[\mathrm{HAI}]_{\text {free }}=[\mathrm{HAI}]_{\text {tot }}-[\mathrm{CuHAI}]$

As is customary, the total acidity was considered to constitute the metal complexing centers of humic substances, so the total acidity content was used in place of the ligand concentration (Stevenson 1982; Senkyr et al.; 1999 Choppin, 1999 Kolokassidou etal. 2009), so

[HAI] tot $=$ total acidity in $\mathrm{meq} / \mathrm{L}$

The value of the formation constant for the $\mathrm{Cu}^{+2}$ humate complex can be calculated by linear regression analysis of the corresponding data using equation (2) in its logarithmic form:

$\log \frac{[\mathrm{CuHAI}]}{[\mathrm{HAI}]_{\text {free }}}=\log \beta-\log \left[\mathrm{Cu}^{2+}\right]_{\text {free }}$

The intercept of the line described by equation (4) corresponds to the logarithmic value of the conditional constant $(\log \beta)$ and the value of the slope to the stoichiometric factor of $\mathrm{Cu}^{2+}$ in the equation of the complexation reaction Kolokassidou et al. 2009).

Fig (5) gives a representation of the experimental data obtained from the above measurements which are presented as log ([CuHAI]/ [HAI] free vis log $[\mathrm{Cu} 2+]$ free. The data results in slope of the curve, $\mathrm{n}=1.0$, indicating that the complexation scheme suggested is correct and $\log \beta$ for the $\mathrm{Cu}$ (II) humate complex $=6.9$. However, Table (6) gives the values of $\log \beta$ obtained in comparison with 
$\log \beta$ for $\mathrm{Cu}^{+2}$ ions binding to humic acids from different sources and Table (7) gives maximum amounts $\mathrm{Cu}+2$ ions removed by HAI in comparison with five commercial humic acids according to the given literatures.

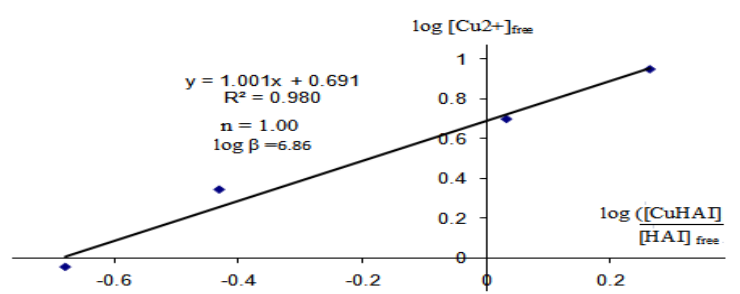

Fig 6 Representation of the experimental data given in Table (5) in terms of meq $/ \mathrm{L}$ of the reacting species
According to these comparisons the conditional stability constant found for $\mathrm{Cu}$ HAI olive cake complex studied is quite comparable to those reported in the literature. In the same time it has the highest ability to remove $\mathrm{Cu}+2$ ions from aqueous solution when compared with five commercial humic acids. Considering these results, it can be said that natural produced olive cake humic acids can absorb high concentrations of $\mathrm{Cu}^{2+}$ ions, making it difficult to be liberated to the soil environment, which is very promise for use as adsorbents in the removal of heavy metals in wastewater treatment processes as natural, safe and gainful compounds.

Table (6) $\log \beta$ of Cu-HAI humate obtained in comparison with $\log \beta$

or $\log \mathrm{K}$ of $\mathrm{Cu}^{+2}$ ions binding to humic acids from some sources

\begin{tabular}{|c|c|c|c|c|c|}
\hline $\log \boldsymbol{\beta}$ & $\mathbf{p H}$ & I $\boldsymbol{i n} \boldsymbol{M}$ & Method & source & Ref \\
\hline 8.3 & 4 & 0.01 & potentiometric Titration & $\begin{array}{c}\text { Stevenson } \\
\text { and Chen(1991) }\end{array}$ \\
\hline 5.2 & 6 & Not reported & $\begin{array}{c}\text { fluorescence quenching } \\
\text { model }\end{array}$ & Soil & Diana et al(.2006) \\
\hline 6.9 & $3.7-4.7$ & 0.002 & Cation exchange method. & $\begin{array}{c}\text { olive-cake } \\
\text { compost }\end{array}$ & Present work \\
\hline 2.33 & 4.0 & 0.01 & exchange-resin & Aldrich & Ivana ,et al. (2011) \\
\hline $4.9-5.7$ & 6.0 & 0.1 & ion selective electrode & $\begin{array}{c}\text { olive-cake } \\
\text { compost }\end{array}$ & $\begin{array}{c}\text { Kolokassidou et al. } \\
(2009)\end{array}$ \\
\hline
\end{tabular}

Table (7) Table Maximum $\mathrm{Cu}^{+2}$ ions removed by HAI in comparison with five Commercial humic acids according to cited literatures

\begin{tabular}{|c|c|c|c|c|c|}
\hline Source & $\begin{array}{c}\text { Fluka AG\& Aldrich } \\
\text { Chemica l Co }\end{array}$ & $\begin{array}{c}\text { Commercial } \\
\text { origins }\end{array}$ & Commercial & HAI & Soil \\
\hline $\mathrm{Cu}+2 \mathrm{in} \mathrm{mg} / \mathrm{g}$ & $51.47 \& 33.68$ & $281 \& 102$ & 100 & 300 & 180 \\
\hline ref & $\begin{array}{c}\text { Beveridge and } \\
\text { Pickering, (1980) }\end{array}$ & $\begin{array}{c}\text { Jordão } \\
\text { et al. (2001) }\end{array}$ & $\begin{array}{c}\text { Barbosa et } \\
\text { al.(2010) }\end{array}$ & $\begin{array}{c}\text { Present } \\
\text { work }\end{array}$ & $\begin{array}{c}\text { Diana et } \\
\text { al. (2006) }\end{array}$ \\
\hline
\end{tabular}

\section{Antimicrobial Evaluation}

Humic acids extracted from compost I ( HAI) was evaluated for their in vitro antibacterial activity against Staphylococcus aureus and Bacillis subtilis as examples of Gram-positive bacteria and Pseudomonas aeruginosa and Escherichia coli as examples of Gram-negative bacteria. They were also evaluated for their in vitro antifungal potential against representative fungal strains i.e. Aspergillus fumigatus, Penicillium italicum and Geotrichum candidum. The organisms were tested against the activity of solutions of concentration $(1 \mathrm{mg} / \mathrm{mL})$ and using inhibition zone diameter in $\mathrm{mm}$ as criterion for the antimicrobial activity (agar well diffusion method) as summarized in Table 8 . As shown by these results, the humic acid preparation displayed good in vitro antibacterial and antifungal action but still lower than the reference drug tested. Bacillis subtilis was the most susceptible microorganism tested. From the screening results, the compound exhibited the highest antibacterial activity measured in 21.9, 21.3, and $9.2 \mathrm{~mm}$ against Bacillus subtilis Staphylococcus aureus, and Escherichia coli, respectively. Interestingly, significant antifungal activity was measured against Penicillium italicum, Geotrichum candidum and Aspergillus fumigatus. 
Table (8) In vitro antimicrobial activity of the tested HAI by well diffusion agar assay expressed as inhibition zone diameter $(\mathrm{mm})$ in the form of mean \pm SD from three replicates.*

\begin{tabular}{|c|c|c|c|c|c|c|c|}
\hline \multirow{2}{*}{$\begin{array}{c}\text { Tested } \\
\text { compounds }\end{array}$} & \multicolumn{2}{|c|}{ Gram-positive bacteria } & \multicolumn{2}{|c|}{$\begin{array}{c}\text { Gram-negative } \\
\text { bacteria }\end{array}$} & \multicolumn{3}{|c|}{ Fungi } \\
\hline & $\begin{array}{l}\text { Bacillus } \\
\text { subtilis }\end{array}$ & $\begin{array}{c}\text { Staphylococcu } \\
\text { s aureus }\end{array}$ & $\begin{array}{c}\text { Escherichi } \\
a \\
\text { coli } \\
\end{array}$ & $\begin{array}{l}\text { Pseudomona } \\
\text { s aeruginosa }\end{array}$ & $\begin{array}{c}\text { Aspergillu } \\
s \\
\text { fumigatus }\end{array}$ & $\begin{array}{l}\text { Penicilliu } \\
\text { m italicum }\end{array}$ & $\begin{array}{c}\text { Geotrichu } \\
m \\
\text { candidum }\end{array}$ \\
\hline Humic acid & $21.9 \pm 0.37$ & $21.3 \pm 0.44$ & $9.2 \pm 0.25$ & NA & $17.2 \pm 0.58$ & $20.9 \pm 0.44$ & $20.3 \pm 0.58$ \\
\hline AmphotericinB* & - & - & - & - & $23.7 \pm 0.10$ & $21.9 \pm 0.12$ & $28.7 \pm 0.22$ \\
\hline Ampicillin* & $32.4 \pm 0.10$ & $27.4 \pm 0.18$ & - & - & - & - & - \\
\hline Gentamicin* & - & - & $22.3 \pm 0.18$ & $17.3 \pm 0.15$ & - & - & - \\
\hline
\end{tabular}

* Amphotericin B; Ampicillin and Gentamycin were used as reference standard; NA: No antimicrobial activity detected under these experimentation conditions; - : Not analyzed
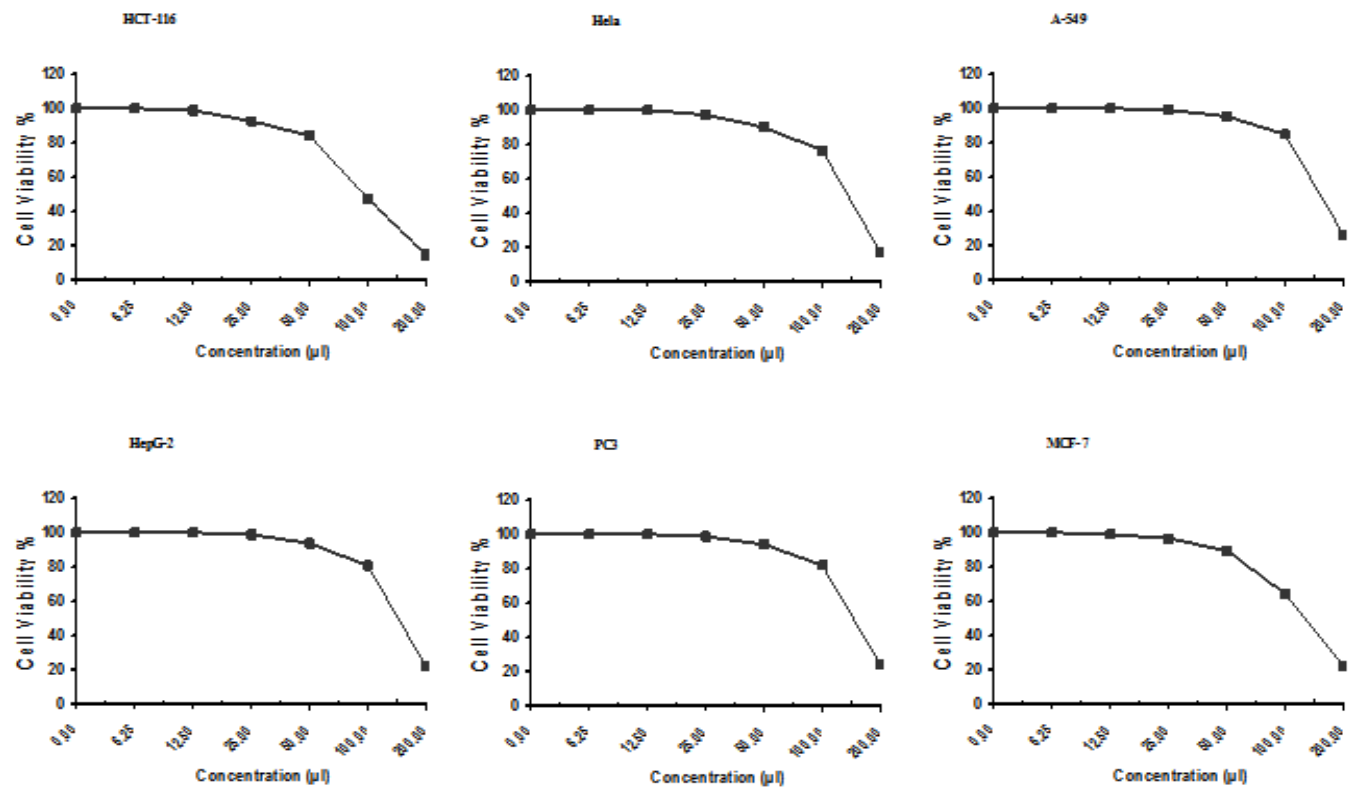

Fig 7: The dose response curve showing the in vitro cytotoxic effect of the humic acid (HAI) against six carcinoma cell lines.

\section{Cytotoxic activity:}

The in vitro growth inhibitory activity of the compound was investigated using MTT assay. Data generated were used to plot a dose response curve of which the concentration of test compounds required to kill $50 \%$ of cell population $\left(\mathrm{IC}_{50}\right)$ was determined and the results revealed that all the tested compounds showed inhibitory activity to the six tumor cell lines in a concentration dependent manner. The humic acid compound exhibited the highest inhibitory effect against colon adenocarcinoma (HCT-116) cell line by $85.37,52.49,16.05,7.33$ and $1.21 \%$ when the cells were treated with $200,100,50,25$, and $12.5 \mu \mathrm{g} / \mathrm{ml}$, respectively (Fig. 6) with $\mathrm{IC}_{50}$ value of $96.6 \mu \mathrm{g} / \mathrm{ml}$. Similarly, the compound showed the inhibitory effect against breast carcinoma (MCF-7), cervical carcinoma (HeLa), hepatocellular carcinoma (HepG2), prostate carcinoma (PC-3), and lung adenocarcinoma (A549) cell lines showing $\mathrm{IC}_{50}$ values of 134,144 , 152,155 and $160 \mu \mathrm{g} / \mathrm{ml}$, respectively

\section{Antioxidant Evaluation}

Also, the synthesized humic acid exhibited good antioxidant activity with $\mathrm{IC}_{50}$ value of $23.2 \mu \mathrm{g} / \mathrm{ml}$ when tested for in vitro DPPH scavenging activity (Fig. 7).

\section{Antiviralal Evaluation}

The synthesized humic acid exhibited weak antiviral activity when tested against herpes simplex virus type $1 \& 2$ at $200 \mu \mathrm{g} / \mathrm{ml}$.

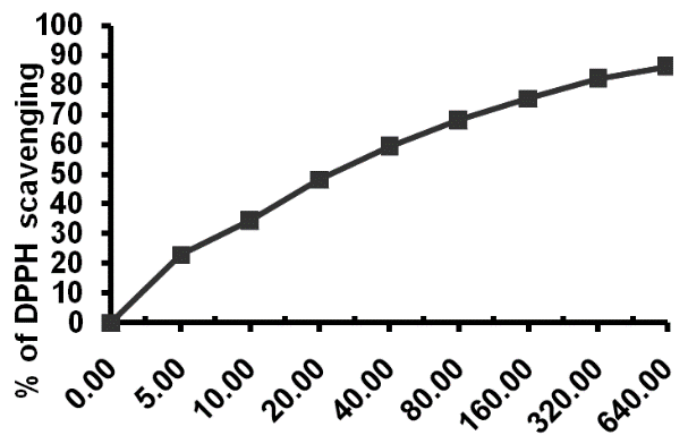

Fig 8: The dose response curve showing the in vitro DPPH Scavenging activity of HAI 


\section{References}

Alken G R, Maccarthy P, Maclom R L and Swift R S (1985) Humic substances in soil, sediment and water. Wiley. New York.

Badr M H (2015) Humic Acid Characterization and nutrients distribution for Some Environmental Samples . Bulletin of the Faculty of Science Alexandria University, 48: under publishing

Badr M H (2003) Studying the chemical characteristics of humic acids extracted from soil and stable manure fuel as a new rich source of humic acid and testing its effects on seed germination. Bulletin of Faculty of Science, Al-Azhar University 14:129140

Barbosa Claudomiro P, Malpass Geoffroy R P, Miwa, Douglas W, Gomes Luciano, Bertazzoli Rodnei, Motheo Artur J (2010) Electrochemical removal of $\mathrm{Cu}$ II in the presence of humic acid. Journal of the Brazilian Chemical Society21: 651-658

Barison C W, Silvab P, Guéganc R, Motelica Heino M, and Sierra M M D (2010) Chemical and spectroscopic characterization of humic acids extracted from the bottom sediments of a Brazilian subtropical micro basin. Journal of Molecular Structure 981:1-3

Barot S N and H K Bagla (2009) Extraction of humic acid from biological matrix dry cow dung powder. Green Chemistry Letters and Reviews 2: 217-221

Beveridge A, Pickering W F (1980) Influence of humate-solute interactions on aqueous heavy metal ion levels. Water Air and Soil Poll 14: 171-18.

Black C A (1965) Methods of Soil Analysis Part 2.American Society of Agronomy: Madison, Wis Schnitzer M (1982) Organic matter characterization. In 'Methods of Soil Analysis Part 2, Chemical and Microbiological Properties Agronomy No. 9. 2nd Edn.

Chatterjee Nirmalya, Markus Flury, Curtis Hinman, Craig G. Cogger (2013). Chemical and Physical Characteristics of Compost Leachates, A Review, Reprt Washington State University 2606 W Pioneer, Puyallup, WA, 98371.

Choppin G R (1999).Role of humics in actinide behavior in ecosystems Chemical Separation Technologies and Related Methods of Nuclear Waste Management. Kluwer Academic Publishers, Dordrecht, Boston, London, pp. 247

Chouliaras N, Vedy J C, Tsadilas C (1998) Speciation of phosphate, $\mathrm{Fe}, \mathrm{Zn}, \mathrm{Mn}, \mathrm{Cu}$ and their availability in soils amended with sewage sludge. Poster presentation and publication. In: Proceedings of the 16 th world congress of soil science Montpellier $p$ $1-8$

De Bertoldi M (1992) The control of the composting process and quality of end products. In: Composting and compost quality assurance criteria. Jackson D $\mathrm{V}$, Merillot J M and L'Hermire p (eds.)

De Pasquale C, Fodale R, Giulivi M, Conte P, Alonzo G (2008) HS-SPME, GC/MS as valid tools to assess volatile organic compounds from soil natural organic system Chemickélisty 102: 265

Debska Bozena, Malgorazata Drag, Erika Tobiasova (2012) Effect of post harvest residues of maize, rapeseed and sunflower on humic acids properties in various soils. Pol J. Envirn Stud 21: 603-613.

Diana Hernandez, CesarPlaza, NicolaSenesi and Alfredo Polo (2006) Detection of copper(II) and zinc(II) binding to humic acids from pig slurry and amended soils by fluorescence Spectroscopy. Environmental Pollution 143: 212-220

Ebtehar R Abdel-al (2011) Extraction of humic acids from different natural sources and studying their reaction with some heavy metals Faculty of Science M.Sc., Thesis, Faculty of Science, Al- Azhar University.

Elaasser, M M, Abdel-Aziz, M M and El-Kassas, R A (2011) Antioxidant, antimicrobial, antiviral and antitumor activities of pyranone derivative obtained from Aspergilluscandidus. J. Microbiol Biotech Res 1:5-17

Eladia M, PeÒa-MÈndez, Josef Havel, Jiřl̀Patočkaz ( 2005 ) Humic substances compounds of still unknown structure applications in agriculture, industry, environment, and biomedicine. J. Appl. Biomed 3: 13-24

Erdogan S, Baysal A, Akba O, and Hamamci C (2007) Interaction of Metals with Humic Acid Isolated from Oxidized Coal. Polish J of Environ Stud 16: 671-675

García A, Baquedano F J, Navarro P, Castillo F J (1999) Oxidative stress induced by copper in sunflower plants. Free Radic Res. 31 :45-50.

Ghabbour A Elham, Geoffrey Davies (2001) Humic Substances: Structures Models and Function. Royal Society of Chemistry (Great Britain) p387.

Ghita Ait Baddi, Mohamed Hafidi, Véronique Gilard, Jean-Claude Revel (2003) Characterization of humic acids produced during composting of olive mill wastes: elemental and spectroscopic analyses (FTIR and 13C-NMR). Agronomie 23: 661-666

Giovanela M , Parlanti E, Soriano-Sierra E J, Soldi M S and Sierra M M D (2004) Elemental compositions, FT-IR spectra and thermal behavior of sedimentary fulvic and humic acids from aquatic and terrestrial environments. Geochemical Journal 38: $255-264$

Gougoulias N, Vagelas I, Vasilakoglou I, Gravanis F, Louka A, Wogiatzi E, Chouliaras N (2010) Comparison of neem and oregano with thiram on organic matter decomposition of a sand loam soil amended with compost, and on soil biological activity. J Sc Food Agric 90:286-29 
GyulaKóródi (2012) Application of humic acids and their derivatives in environmental pollution control. AARMS Technology 11: 61-65

Helena D, Sławomir G, Witold P (1994) Properties of humic acids of arctic tundra soils in Spitsbergen. Polish Polar Research, 15: 71-81

Iheoma M Adekunle, Toyin A Arowolo, Naomi P Ndahi, Babajide Bello and David A Owolabi (2007) Chemical characteristics of humic acids in relation to lead, copper and cadmium levels in contaminated soils from south west Nigeria. Annals of Environmental Science 1: 23-34

Ivana Kosti, Tatjana Anđelkovi, Ružica Nikoli, Aleksandar Bojić1, Milovan Purenovi, Srđan Blagojevi and Darko Anđelkovi (2011) Copper(II) and lead(II) complexation by humic acid and humic-like ligands. Serb Chem Soc76:1325-1336

James A. Rice, Patrick Mac Carthy (1991) Statistical evaluation of the elemental composition of humic substances. Organic Geochemistry 17: 635-648

Jelković Tatjana Darko, elkovć Jelica Perović, Milovan Purenović , Predrag Polić (2001) Decrease of oxygen interference on humic acid structure alteration during isolation. Factauniversitatis Series: Physics, Chemistry and Technology 2: 163171.

Jordão Cláudio Pereira, Reis César Bellato, Carlos Roberto, Jham, Gulab Newandram, Pereira, José Luis. (2001). Adsorption of $\mathrm{Cu} 2+$ ions on humic acids. Rem Revista Escola de Minas 54: 109-114.

Kim G Tan (1998) Principles of soil chemistry Marcel Dekker.

Kim J I, Buckau G, Li G H, Duschner H, sarros N P (1990) Characterization of Humic and Fulvic Acids from Gorleben Ground water. Fresenius Journal of Analytical Chemistry 338: 245-252

Klančnik A, Piskernik S, Jeršek B and Elaasser, M M , Abdel-Aziz, M.M. and El-Kassas R.A. Možina S S (2010) Evaluation of diffusion and dilution methods to determine the antibacterial activity of plant extracts. Journal of Microbiological Methods 81: $121-126$.

Kolokassidou, K W , Szymczak M ,Wolf C Obermeier, Buckau G, Pashalidis I (2009) Hydrophilic olive cake extracts: Characterization by physicochemical properties and $\mathrm{Cu}(\mathrm{II})$ complexation . Journal of Hazardous Materials 164 : 442-447

KovácsK , Gáspár A Cs, Sajgó P, Schmitt Kopplin and Tombácz E (2012) Comparative study on humic substances isolated in thermal ground waters from deep aquifers below $700 \mathrm{~m}$. Geochemical Journal 46: $211-224$

Lis G P, Mastalerz M, Schimmelmann A, Lewan M D and Stankiewicz B A (2005) FTIR absorption indices for thermal maturity in comparison with vitrinite reflectance RO in type-II kerogens from
Devonian black shales.Org Geochem 36: $1533-$ 1552

Lobartini J C, Tan K H, Rema J A, Gingle A R, Pape C, Heimmelsbach D S (1992) The geochemical nature and agricultural importance of commercial humic matter. The Science of the Total Environment 113: 1-15

Madejon E, Galli E, Tomati U (1998) Composting of wastes produced by low water consuming olive mill technology. Agrochimica 42: 135-146

Makarov M I (1990) Studies of amino acid composition of soil humicacid: methodological aspect. Moskov University-Soil-Science-Bulletin 45: 26-31

Maris Klavins, Oskars Purmalis, Valery Rodinov( 2013) Peat humic acid properties and factors influencing their variability in a temperate bog ecosystem. Estonian Journal of Ecology 62: 3552.

Ministry of Agriculture and Land Reclamation, General Administration of culture, agricultural ,Technical Bulletin No.3/2004 Issued by the General Directorate of Agricultural Culture. Egypt

Mohammad Arifur Rahman, Abu Hasan M d, Abdur Rahim, A M Shafiqu Alam (2010). Characterization of Humic Acid from the River Bottom Sediments of Burigonga: Complexation Studies of Metals with Humic Acid. Pak J Anal Environ Chem 11: 42-52

Mosmann T (1983) Antioxidant, antimicrobial, antiviral and antitumor activities of pyranone derivative obtained from Aspergilluscandidus. J Microbiol Biotech Res 1:5-17.

Naděžda Fasurov, Lubica Pospíšilov (2010) Characterization of soil humic substances by ultraviolet-visible and synchronous fluorescence spectroscopy.by Journal of Central European Agriculture 11: 350-357

Naidja P M, Huang, D W Anderson, C Van Kessel (2002) Fourier transform infrared, uv-visible, and $\mathrm{x}$-ray diffraction analyses of organic matter in humin, humic acid, and fulvic acid fractions in soil exposed to elevated $\mathrm{CO} 2$ and $\mathrm{N}$ fertilization. Applied Spectroscopy 56: 318-324

Negro M J , Solano M L (1996) Laboratory composting assays of the solid residue resulting from the flocculation of oil mill waste water with different lignocelluloses residues. Compost Sci 1: 62-71.

Orlov D S, 1985. Humus Acids of Soils. A. A. Balkema Press.Rotterdam Netherlands

Kim H. Tan (2014) Humic Matter in Soil and the Environment: Principles and Controversies CRC Press, Amazon.com.

Paredes C, Roig A, Bernal M P, S! anchez Monedero M A, Cegarra I (2000) Evolution of organic matter and nitrogen during co-composting of olive mill wastewater with solid Fertil Soils 32: 222-227 
Peruma Palanivell, KasimSusilawati, OsumanuHaruna Ahmed,Nik Muhamad Majid (2013) Compost and Crude Humic Substances Produced from Selected Wastes and Their Effects on Zea mays L Nutrient Uptake and Growth. Scientific World Journal 2013: 15 pages

Polak J , Sułkowski W W (2006) "Influence of the Treatment Process on Nitrogen Content in Humic Acids Extracted from Sewage Sludge. Polish. J of Environ Stud 15: 573-577

Prasad M N, Kazimier Strzalka (2002) Physiology and Biochemistry of Metal Toxicity and Tolerance in Plants p 225.

Rebhun M, Meir S, Laor Y (1998) Using dissolved humic acids to remove hydrophobic contaminants from water by Complexation-flocculation process. Environ Sci Technol 32: 981-986

Rice J A ,Mac Carthy P (1991) Statistical evaluation of the elemental composition of humic substances. Organic Geochemistry 17: 635-648.

Schnitzer M, Khan U (1978) Soil Organic Matter. New York, Elsevier.

Schnitzer M ,Umesh C Gupta (1965) Determination of acidity in soil organic matter Soil Science society proceedings $29: 274-277$.

Senesi N, Plaza C, Brunetti G, Polo A (2007) A comparative survey of recent results on humic-like fraction in organic amendments and effects on native soil humic substances. Soil Biol Biochem 39:1244-1262

Senkyr J, Rocakova D, Fetsch D, Havel J, (1999) The acidic - basic and complexation properties of humic acids II. Study of humic acids complexation with cadmium and lead by pulse anodic stripping voltammetery.Tox Environ Chem 33: 1-15.

Sim Siong Fong, Lau Seng, Norrafidah Majri, Haslinda Mat (2007) A comparative evaluation on the oxidative approaches for extraction of humic acids from low rank coal of Mukah, Sarawak. J Braz Chem Soc 18 : 34-40

Sparks D L(1999) Soil Physical Chemistry, Department of Plant and Soil Sciences University of Delaware CRC.

Stevenson F J (1994) Humus Chemistry: Genesis, Composition, Reactions. 2nd ed. Wiley, New York, pp. 496

Stevenson F J, (1982). Humus Chemistry Genesis, Composition, Reactions. Wiley-Inter science, New York.

Stevenson F J, Y Chen (1991) Stability Constants of Copper(II)-Humate Complexes Determined by Modified Potentiometric Titration . Soil Sci Soc Am J, 55:1586-1591

Swift R S (1996) Organic matter characterization (chap 35). pp. 1018-1020. In D.L. Sparks et al. (eds) Methods of soil analysis. Part 3.Chemical methods. Soil Sci Soc Am Book Series: 5 Madison, WI.

Theng G K B, Wake R J, Posner M M, (1967) The humic acids extracted by various reagents from a soil ii. infra-red, visible, and ultra-violet absorption spectra J. of Soil Science 18: 349-363.

Vijayan P , Raghu C, Ashok G, Dhanaraj S A and Suresh B (2004) Antiviral activity of medicinal plants of Nilgiris. Indian J. Med. Res. 120: 24-29

Xi J. and Schaich K M (2014) Re-evaluation of the 2,2-Diphenyl-1-picrylhydrazyl Free Radical (DPPH) Assay for Antioxidant Activity.Journal of Agricultural and Food Chemistry, 62 : 4251-4260

Yamamoto S, Honna T, Snatani N, Limura K (1994) Influence of temperature on diluted sodium hydroxid soluble humus properties. Denaturation of humus extracts caused by heating in boiling water .Pedologist 38: 31-38.
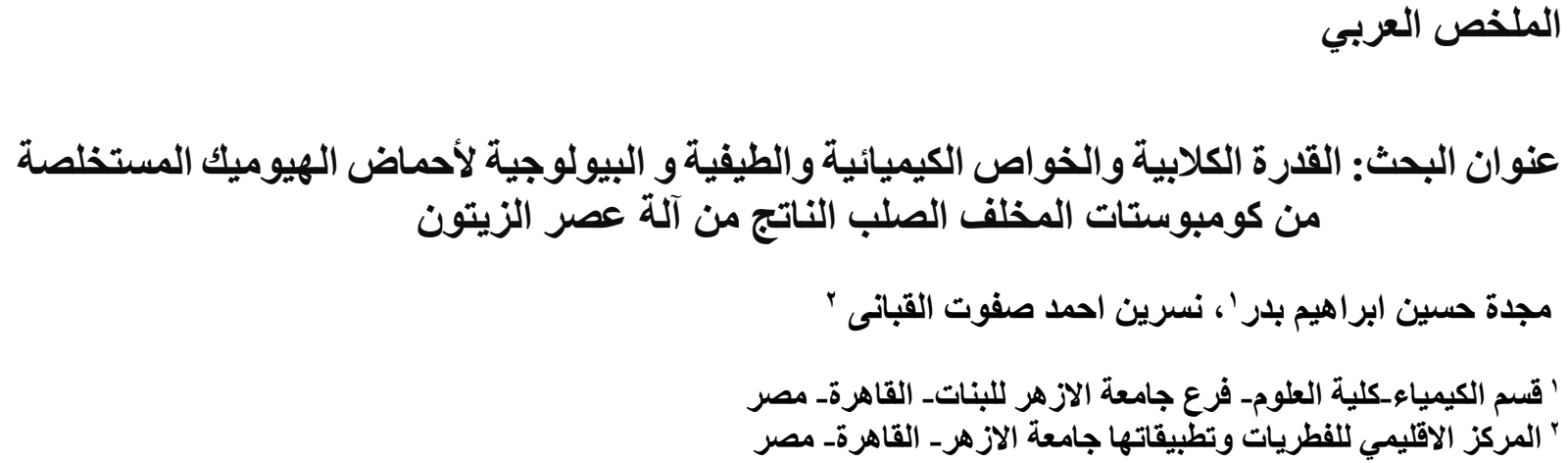

لقد خلص الى ان الابحاث و الاراسات على احماض الهيوميك ضرورية لتربة صحية ومنتجة ولابد للمختصين من فحص هذه الاحماض كيميائيا وتقدير الكيميات التلازمة منها للتسميد ، حتى تتحقى الوفي الوفرة

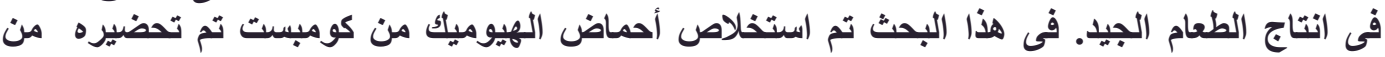




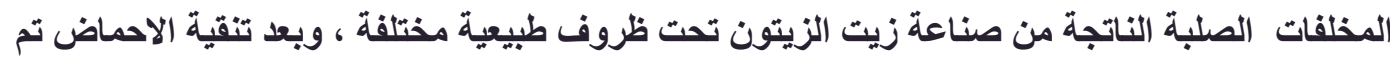

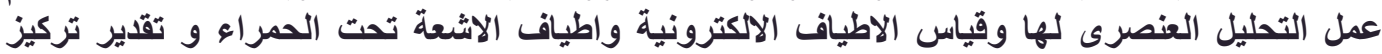

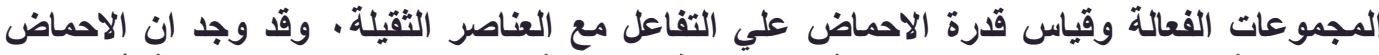

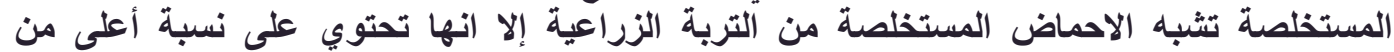

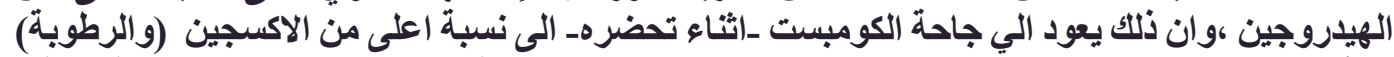

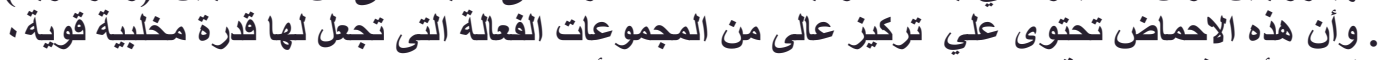

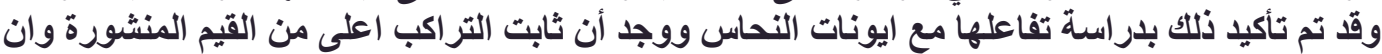

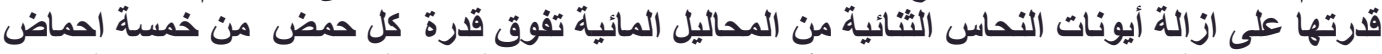

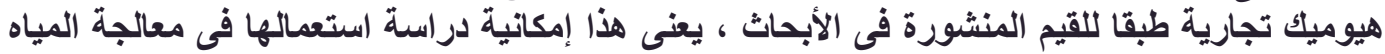

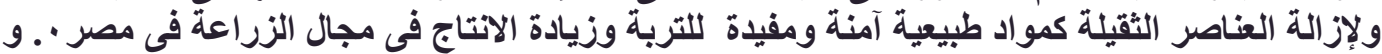

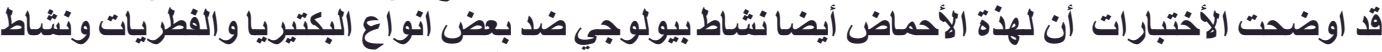
ضعيف ضد الفيروسات والات ألاورام كما أن لها قارة مؤُشرة كمضادة للأكسدة. 